\title{
漢方の国際化時代における漢方教育のあり方
}

\author{
牧野利明
}

\section{How to Teach Kampo Medicine in the Age of Internationalization?}

\author{
Toshiaki Makino \\ Graduate School of Pharmaceutical Sciences, Nagoya City University; \\ 3-1 Tanabe-dori, Mizuho-ku, Nagoya 467-8603, Japan.
}

(Received August 18, 2015)

\begin{abstract}
Given the universal prevalence of complementary and alternative medicines, as well as integrative medicine, the usage of traditional medicine has been gaining in popularity worldwide. Japanese Kampo medicine and traditional Chinese medicine (TCM) are both derived from ancient medicines used in East Asia in the 5th-7th centuries, and have developed independently since the 14th century. Now Kampo medicine and TCM have different theories for the diagnosis and use of crude drugs. Unfortunately, Kampo medicine is not well known in Europe and the Americas; as a matter of practice, TCM is the international standard for traditional medicines derived from ancient East Asia. In the teaching of Kampo medicines to undergraduate students in a school of pharmacy, the author considers that a minimum requirement is to explain the differences between TCM and Kampo medicine. For graduate students of pharmaceutical science, the students must know the distinct medical theories of both TCM and Kampo medicine, and furthermore, must be able to read and write articles in English about traditional medicines, in order to help put Kampo medicine on the world map.
\end{abstract}

Key words — Kampo medicine; traditional Chinese medicine; internationalization; education

\section{緒言}

現在では世界レベルでの補完代替医療（complementary and alternative medicine; CAM) のブー ムが起こっており, 現代西洋医学の枠外での医療行 為が着目されるようになってきた。アメリカでは 1992 年にアメリカ国立衛生研究所（National Institutes of Health; NIH）にアメリカ国立補完代替医 療センターが設置され，2014 年 12 月にはアメリカ 国立補完統合衛生センター（National Center for Complementary and Integrative Health; CCIH) に 発展的に改称している。統合医療には，針やマッ サージ，心身療法などが含まれるが，アメリカで最 も利用率の高いのは，ビタミンやミネラルを除く植 物などを原料とするダイエタリーサプリメントであ る. 1) また，植物療法の歴史のあるヨーロッパでは， 2004 年にヨーロッパ医薬品庁が制定した伝統的植

名古屋市立大学大学院薬学研究科（T467-8603 名古屋 市瑞穂区田辺通 3-1)

e-mail: makino@phar.nagoya-cu.ac.jp 本総説は, 日本薬学会第 135 年会シンポジウムS56 で 発表した内容を中心に記述したものである。
物由来医薬品に関する指針品質が確保された，生薬 を原料にした一般用医薬品が販売されていると同時 に，アメリカと同様，植物を原料とする機能性食品 も多く利用されている. そのような食品の中には, 中国伝統薬物を起源とするものもあり, 東洋医学で 利用する生薬を原料にした製剂が鍼众院や伝統医学 を取り扱う医療施設で利用されている。ここでは, 日本製の生薬製剤，漢方製剤の利用は極めてマイ ナーであり，ほとんどが中国製の製剤である.

現在の中国では，自国で生産する生薬とそれを原 料とした製剤を，世界中に販売して利益を得ようと する試みを，国を挙げて行ってきている，中国伝統 医学 (中医学) の医師たちは，早くから中国で利用 されている生薬や処方, 中医学における理論の英訳 化に着手してきており，特に Bensky らが出版した 生薬一覧 ${ }^{2)}$ と処方集 ${ }^{3)}$ は，中医学で使用される中薬 （生薬）の基原と用途，処方の構成，用法，用量な どが英語で執筆され，海外における中医学での薬物 療法の教科書となっている。ささら中国は, 2009 年に国際標準化機構 (International Organization for Standarization； ISO）に中国伝統医学（tradi- 
Table 1. Differences between Traditional Japanese Kampo Medicine and Traditional Chinese Medicine

\section{Japanese Kampo medicine}

All physicians and pharmacists have to learn Western medicine. There is little pharmacological theory in each crude drug in the formula.

The formula is fixed, and the physicians/pharmacists usually do not change the components.

The amount of crude drugs is smaller than in TCM, about $30 \mathrm{~g} / \mathrm{d}$ in usual.
Traditional Chinese medicine

School and license are separated from Western medicine.

Each crude drug has each theory about traditional pharmacology (concept).

Physicians/pharmacists usually change components of the formula depending on patients' condition.

The amount of crude drugs is larger, more than $100 \mathrm{~g} / \mathrm{d}$ in usual. tional Chinese medicine）に関する専門委員会の設 置を申請し，中国における薬局方である中国薬典4) や Bensky らの教科書 ${ }^{2,3)}$ の内容などを国際標準とし ようと目論んでいる. 中国の提案がそのまま国際標 準となれば，日本で使用される生薬の品質を確保し ている日本薬局方や, 生薬製剤, 漢方製剤の規格書 を中国のものに合わせなければならなくなる可能性 もあり, 日本の数少ない専門家たちが日本の規格を 守るべく必死になって対応している段階にある.5) しかし, 世界レベルでは日本の漢方医学と中医学の 違いはほとんど理解されておらず，日本国内におい ても漢方の本場が中国と思っている一般人は多い. この点では, 薬学教育の中に「漢方医学と中医学の 違いを説明できる」という技能は必須と思われる. とくに日本の漢方医学は国際化という点では中国に 大きく遅れをとっており，また日本の一般の方に対 する啓蒙も不足しているため，その違いを世界レべ ルで説明できる人材を育成できる教育が求められる.

\section{漢方医学と中医学の違い}

漢方医学は，3-6 世紀頃の中国大陸における医学 を起源とし，その後は日本で独自に発展した日本に おける伝統医学を言い, 現在, 中国で行われている 中医学とは異なるものである. 実際に, 長い歴史の 間で日本民族に適した生薬の利用方法を考案した り，中国大陸からの輸入に頼らなくてすむよう日本 に自生する植物を原料とした生薬を利用したりする など，多くの生薬で日本と中国とで同じ文字を使つ て表現されるのに，その基原植物や使用部位が異 なっている，有名なところでは，「当帰（当归）」は 日本ではセリ科 Angelica acutiloba の根を基原とす るが，中国では A. sinensis の根，「川芦」は，日本 ではセリ科 Cnidium officinale の根茎を基原とする が，中国では Ligusticum chuanxiong の根茎，など
である．また，ショウガ科 Zingiber officinale の根 茎を乾燥させたものは, 日本では生姜, 中国では干 姜と，異なる生薬名で表現する，さらに，1日あた りの処方に配合される薬用量も異なり, 中国での用 量は日本の約 3-4 倍量を使用する（Table 1).

また, 生薬の使い方, すなわち, 疾患の診断, 治 療方法も, 漢方医学と中医学では大きく異なってい る. 漢方医学の特徵は,「方証相対」と呼ばれる処 方の運用方法である。この「方」は複数の生薬が配 合された処方のことを指し，「証」は漢方医学にお ける病態を指すので, 漢方医学における診断名と使 用する処方名が相対している，ということである. 実際, 漢方医学でのバイブルとされる『傷寒雑病論』 では，○○という症状を持つ患者に対しては， $\Delta \Delta$ 湯を飲ませなさい，という記述が羅列され，臨床に おいてはたいへん都合のよい一方で，どうしてその 処方を使えば治るのかの議論が少なく, 医学の基礎 となる生理学, 病理学を問わないでブラックボック ス化してしまっている.いくら『傷寒雑病論』には 様々な患者の症状が羅列されているとは言え, すべ ての患者の症状に対応することは不可能であるが, そのブラックボックスは様々な考え方を導入するこ とができる柔軟性を持っており，『傷寒雑病論』の 文章の行間を解析して様々な処方の運用方法をトラ イアルして得られた経験則（口訣）や，現代の和漢 診療学で使用される気血水のスコア, さらには現代 においては主流を占める病名漢方と呼ばれる西洋医 学的な処方の運用方法や, 根拠に基づく医療（evidence based medicine; EBM）までも導入すること ができ, 日本では現代医学の中に伝統医学がうまく 溶けこんでいる状態にある（Fig. 1). $\left.{ }^{6}\right)$ 日本では, 漢方薬は, 一般用, 医療用ともに西洋医学での病名 での適応を持ち, 西洋医学を学んで免許を取得した 


\title{
Diagnosis (方証相対) Treatment
}

\author{
Diagnose the conditions of \\ patients by the description \\ in the textbook depending \\ on the achievements of \\ The formula is automatically \\ determined.
}

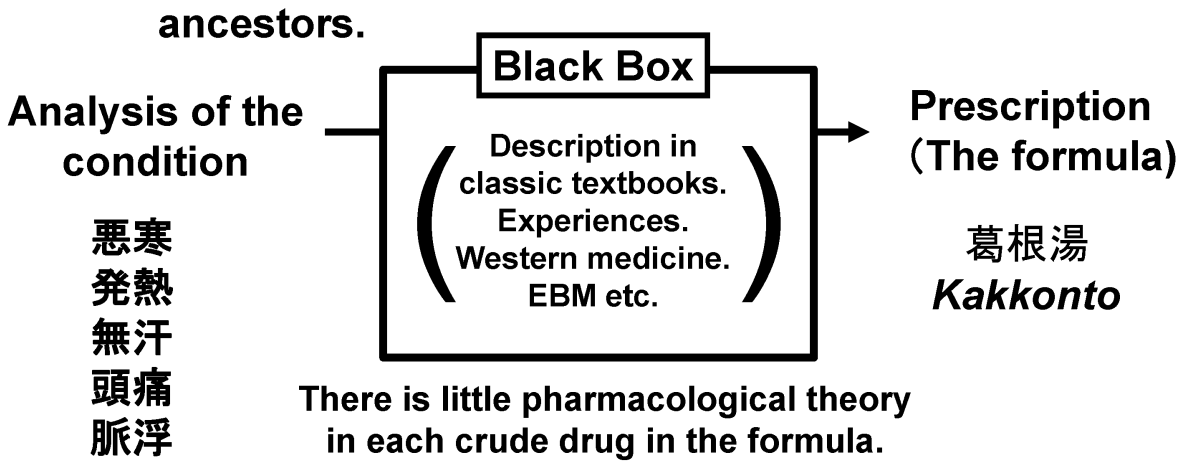

Fig. 1. Scheme of Diagnosis and Treatment in Kampo Medicine

医師，薬剤師が使用するため，伝統医学用語を使用 しなくても西洋医学の枠組みの中で漢方薬を利用し て, その効果の解釈, 検証は現代科学的に行うこと ができる.

一方，現代の中医学では，「弁証論治」と呼ばれ る処方の運用方法が特徵となっている. すなわち, 患者を伝統医学における生理学, 病理学の考え方を 用いて診断（弁証）し，その疾患の原因が明らかに なればそれを取り除くために，個々の生薬にあてが われている薬能（伝統医学におけるクスリとしての 作用）を用いて生薬を配合し，処方を投薬して治療 する（論治）という方法である。この, 生理・病理 学の理論を基に疾患の原因を考え, 個々の薬物を薬 理学の理論に従って処方を組んで薬物療法を行う, という論理展開は, 現代西洋医学とよく似ており, 現代科学を学んだ者にとってはなじ夕易いものの, 理論の中で使用する 1 つ 1 つの概念は現代西洋医学 では説明し難い（Fig. 2)。これは，中国では中医 学と西洋医学の医師免許が分かれており（二元的医 療制度)，それぞれが独立した形で並存しているた め, これまで両者の橋渡しをする必要がなかつたこ とが背景にあると考えられる。ささすがに現在では, 科学的なエビデンスが求められるようになり, 二重 盲検などにより臨床方面での統計学的なエビデンス 研究は進みつつあるが, 伝統医学の概念を現代生
理, 病理学的に科学化する試みはほとんど行われて いない，この点では，日本の一元的医療制度は，漢 方医学の科学化にはおおいに役に立っている.

\section{生薬学と漢方薬学教育の連携}

薬学の立場から漢方医学を教育するときに困るの は，漢方処方を構成する生薬の取扱いである，生薬 学は現代科学における学問であり, 薬学部の学生は 生薬の基原や含有成分, 実験や臨床的に認められて いる薬理を科学的に学ぶわけだが，それでは漢方処 方に配合される生薬個々の役割を説明することがで きない，例えば，麻黄にはエフェドリンが含まれて おり，その $\beta$ 受容体刺激作用により気管支を拡張 することで鎮咳作用を示すので，かぜ薬として使用 される麻黄湯や葛根湯に配合される，とは説明でき るが，なぜ関節痛やリウマチに使用される越婢加术 湯や薏荝仁湯に配合されるかは説明できない。これ では, 学生はせっかく生薬学を学んでいるのに, そ れを漢方薬の学習に活かすことができないことに なってしまう.

そこで筆者は, 日本で使用されている漢方処方に 構成されている個々の生薬の配合目的を解棌するた めに, 中医学における薬物理論である中薬学を採用 している.さきほどの麻黄の中薬学における薬能は 「辛温解表」であり，鼻口腔粘膜や手足の関節など 漢方医学における「表」と呼ばれる部位に「寒邪」 


\section{Diagnosis (弁証)}

\section{Consider the reason of diseases by traditional physiological and pathological theory.}

Treatment (論治)

\author{
Use crude drugs that can \\ solve the reason of the \\ diseases by traditional \\ pharmacology.
}

Treatment Analysis of the
condition Diagnosis to cure the diseases Prescription
(The formula)

\section{寒証 表実証 風寒襲表}

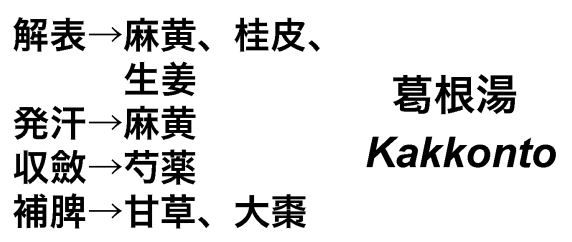

Mix according to traditional pharmacology of each crude drug.

Fig. 2. Scheme of Diagnosis and Treatment in Traditional Chinese Medicine (TCM)

が侵襲し，その寒さによって体内を循環している水 が発散できずに停滞して病理産物となつた「湿邪」 に対して，「表」を温めて汗とともに体外へ追い出 す，という作用である。すなわち，鼻水や関節痛 を，それぞれの部位が冷やされて本来は水蒸気とし て発散されるべき水が貯まってしまった結果として 生じていると弁証し, 辛温解表作用を持つ麻黄が鼻 口腔粘膜の異常にも関節の異常にも運用される, と 説明ができるのである.

このように, 漢方医学で使用する処方を構成する 個々の生薬を, 中薬学で使用する薬能を組み合わせ ることにより, 処方の大まかな適応を理解すること ができ, 結果的に個々の生薬と漢方処方をリンクさ せることが可能となる.すなわち, 生薬を基礎とし た漢方処方の理解が容易になる。この方法は, 生薬 を組み合わせることの妙については説明することは できないが，初心者に対する漢方教育としてはおお いに有用と考える. 漢方医学と中医学は対立するも のではなく，お互いに論理が未熟で補完し合う関係 にあると筆者は考えており，日本漢方と中医学の両 者を「いいとこ取り」して，さらに発展していきた いと考えている.

\section{国際化時代の漢方教育}

現時点では漢方薬，漢方医学は残念ながら日本国 内のみでしか通用せず，海外では中医学のほうが圧 倒的に優勢である。しかし，日本の漢方薬は一部の 国の補完代替医療に係わる医師においてその高い品 質の漢方製剤のよさが知られており，極めてマイ ナーではあるがアメリカでは一部の漢方製剤がダイ エタリーサプリメントとして利用されるものの, ヨーロッパでは生薬製剤の品質に関する基準が厳し く利用できない状態となっている.

そのような中での薬学部での漢方教育では, 欧米 人からは全く同一視されている中医学と日本漢方の 違いを説明できることが少なくとも目標とする技能 として必須であると考える。事実上，中医学が中国 大陸を起源とする伝統医学の世界標準となってし まっている中では，中医学に関する知識も最低限は 必須であるが，それを踏まえることで日本の漢方医 学と漢方薬の優位な点, 不利な点が理解できるよう になる。

さらに，大学院レベルのアドバンス教育として は, 日本の漢方医学と中医学の違いを英語で主張し て世界にアピールできることが望ましい，近年で は, 古代中国医学を起源とする伝統医学 (漢方医 学, 中医学, 韓医学ほか) で使用される薬物を用い 
た，英語で記述された基礎，臨床報告が，数多く出 版されるようになってきた。海外からの伝統医学に 関する論文には，二重盲検を使用した西洋医学から の批判にも十分に答えられる臨床報告もある一方 で，研究材料として使用した生薬の基原の記述があ いまいで品質が疑わしい材料を用いた報告など，そ の質には大きなバラツキがある。そのような論文を 整理して伝統医学における医薬品情報を国内へ発信 できる能力とともに，日本の漢方医学を世界に発信 する技術の習得を期待したい.

利益相反＼cjkstart開示すべき利益相反はない.

\section{REFERENCES}

1) Clarke T. C., Black L. I., Stussman B. J., Barnes P. M., Nahin R. L., Natl. Health Stat. Report, No. 79, 1-16 (2015).
2) Bensky D., Clavey S., Stoger E., "Chinese Herbal Medicine: Materia Medica," 3rd ed., Eastland Press, Seattle, 2004.

3) Scheid V., Bensky D., Ellis A., Barolet R., "Chinese Herbal Medicine: Formulas \& Strategies," 2nd ed., Eastland Press, Seattle, 2009.

4) Pharmacopoeia Commission of the Ministry of Health of the People's Republic of China, "The Pharmacopoeia of the People's Republic of China 2010 Edition," China Medical Science Press, Beijin, 2010.

5) Special Edition for the international standardization and Kampo medicine with a focus on ISO/TC249, Kampo \& the Newest Therapy, 22, 3-48 (2013).

6) Yasui H., "Igakusei no tameno Kampo Igaku," Toyo Gakujutsu Shuppansha, Ichikawa, 2011. 